\title{
Erratum behorend bij: Stoornissen in primaire mondfucties
}

Erratum behorend bij:

H.F.M. Peters, R. Bastiaanse, J. Van Borsel,

P.H.O. Dejonckere, K. Jansonius-Schultheiss,

Sj. Van der Meulen, B.J.E. Mondelaers,

Stoornissen in primaire mondfuncties,

https://doi.org/10.1007/978-90-368-0806-4

Er stond helaas een storende fout in de titel in het voorwerk van de online versie van dit boek. Dit is nu gecorrigeerd.

De bijgewerkte online versie van het boek kan hier worden geraadpleegd:

https://doi.org/10.1007/978-90-368-0806-4

(C) 2018 Bohn Stafleu van Loghum is een imprint van Springer Media, onderdeel van Springer Nature

H.F.M. Peters, R. Bastiaanse, J. Van Borsel, P.H.O. Dejonckere, K. Jansonius-Schultheiss, $\mathrm{Sj}$. Van der Meulen, B.J.E. Mondelaers, Stoornissen in primaire mondfuncties, https://doi.org/10.1007/978-90-368-0806-4_12 